\title{
SOIL FAUNA AS BIOINDICATOR OF RECOVERY OF DEGRADED AREAS IN THE CAATINGA BIOME ${ }^{1}$
}

\author{
KHADIDJA DANTAS ROCHA DE LIMA ${ }^{2 *}$, RODRIGO CAMARA ${ }^{3}$, GUILHERME MONTANDON CHAER ${ }^{4}$, \\ MARCOS GERVASIO PEREIRA ${ }^{5}$, ALEXANDER SILVA DE RESENDE ${ }^{4}$
}

\begin{abstract}
Information on the recovering of areas of gravel extraction of the Caatinga biome are scarce. Thus, the objective of this work was to assess the soil fauna as bioindicator of soil quality, evaluating areas with addition of topsoil (WAT) and control areas (CWT) without the addition of topsoil used for forest plantations, which were implemented for recovering gravel extraction areas. A native forest of the Caatinga biome (NFC) was taken as a reference. Ten traps with three replicates were installed in each area, which were evaluated in a randomized block design in split-plot arrangement at the end of the rainy season of different years, $0,1,3$ and 6 years after the experiment implementation. A total of 45,740 specimens were captured. These specimens were from 36 taxonomic groups. The Acari, Diptera, Entomobryomorpha, Formicidae, Poduromorpha and Symphypleona were the predominant groups in all areas (WAT, CWT and NFC). Nine groups $(25 \%$ of the total) had restricted occurrence. The fauna richness and diversity were higher in the NFC, followed by the WAT and CWT. The uniformity and total abundance of the soil fauna community showed no defined patterns. The abundance of most groups was inhibited in the treatments evaluated, compared with NFC, however, this adverse effect was more significant in CWT compared with WAT. The CWT and WAT had high similarity and both had very low similarity with NFC. The ecological complexity of soil fauna community was higher in NFC. The soil fauna was efficient as a bioindicator of soil quality, which was higher in WAT, compared with CWT.
\end{abstract}

Keywords: Topsoil. Environmental indicators. Soil organisms. Gravel. Revegetation.

\section{FAUNA EDÁFICA COMO BIOINDICADORA DA RECUPERAÇÃO DE ÁREAS DEGRADADAS NO BIOMA CAATINGA}

RESUMO - Atualmente, há poucas informações sobre a recuperação de áreas onde ocorre a extração de piçarra na Caatinga. Objetivou-se avaliar o emprego da fauna edáfica como bioindicadora da qualidade do solo em áreas com e sem a adição de topsoil (CT e ST, respectivamente), em plantios florestais para a recuperação de áreas de extração deste recurso mineral. Considerou-se a mata nativa de Caatinga (MT) como referencial. Foram instaladas 10 armadilhas em três réplicas para cada tratamento, em delineamento em blocos casualizados em esquema de parcelas subdivididas, no final da estação chuvosa,em diferentes épocas (0, 1, 3 e 6 anos depois). Capturou-se um total de 45.740 organismos, distribuídos em 36 grupos taxonômicos, com o predomínio de Acari, Diptera, Entomobryomorpha, Formicidae, Poduromorpha e Symphypleona, em todos os tratamentos (ST, CT, MT). Nove grupos (25\% do total) apresentaram ocorrência restrita. Os valores de riqueza e diversidade foram maiores na MT, seguidos do CT e ST. Não houve um padrão definido para a uniformidade e abundância total da comunidade. A maioria dos grupos apresentou inibição na abundância nos tratamentos testados em relação à $\mathrm{MT}$, mas este efeito negativo foi relevante no ST, em comparação com o CT. A similaridade entre ST e CT foi elevada, e muito baixa com a MT. A complexidade ecológica da comunidade da fauna edáfica foi maior na MT. A fauna edáfica funcionou como bioindicadora da qualidade do solo, que foi maior em CT, na comparação com ST.

Palavras-chave: Solo superficial. Indicadores ambientais. Organismos edáficos. Piçarra. Revegetação.

\footnotetext{
*Corresponding author

${ }^{1}$ Received for publication in $03 / 22 / 2016$; accepted in 08/29/2016.

${ }^{2}$ Soil Department, Universidade Federal Rural do Rio de Janeiro, Seropédica, RJ, Brazil; khadidjadantas@hotmail.com.

${ }^{3}$ Department of Environmental Science, Universidade Federal Rural do Rio de Janeiro, Seropédica, RJ, Brazil; rcamara73@gmail.com.

${ }^{4}$ Embrapa Agrobiology, Seropédica, RJ, Brazil; guilherme.chaer@embrapa.br, alexander.resende@embrapa.br.

${ }^{5}$ Soil Department, Universidade Federal Rural do Rio de Janeiro, Seropédica, RJ, Brazil; mgervasiopereira01@gmail.com.
} 


\section{INTRODUCTION}

Different human activities can modify landscapes, reducing the resilience of the altered areas, requiring in some cases, human intervention to facilitate and accelerate the recovery of the ecosystem functions. Therefore, one of the commonly used practices is the planting of forest species, which covers the ground, minimizing the effects of erosion (BATISTA et al., 2008; FERREIRA et al., 2010). Moreover, these plantations can restart the forest succession process, favoring the nutrient cycling through the input of organic matter.

The removal of the soil surface layer (topsoil) for extraction of gravel, which is a mineral material found in the subsoil, mainly composed of silt, sand and grit (RESENDE et al., 2010), is common in the Caatinga biome of the State of Rio Grande do Norte $(\mathrm{RN})$, Brazil. This material is used for ground levelling of onshore sites of oil extraction and processing, which is one of the main economic activities of this state (LIMA et al., 2015), as well as for landfill, and dam and road constructions.

The topsoil is the soil layer that has the highest natural fertility (MARTINS et al, 2015) and is an important source of propagules (LEAL FILHO; SANTOS; FERREIRA, 2013). Therefore, the addition of topsoil on degraded soils before the implementation of forest plantations is recommended, in order to facilitate the area recovery process. However, the subsoil exposed after the gravel extraction in areas of the Caatinga biome is usually rich in nutrients, thus, this expensive practice, does not necessarily leads to an increase in fertility of the remaining subsoil (RESENDE et al., 2010). Still, several authors recommend this practice to increase the richness of species that regenerate these areas, through the seed bank of the topsoil.

Therefore, the effectiveness of the addition of topsoil needs evaluation to choose the best alternative for recovery degraded areas in similar situations; and the soil fauna emerges as a promising tool. The soil fauna community can be used as bioindicator of the effects of different treatments on the recovery of degraded areas, regarding the soil quality. This is based on the activity of these invertebrates, which are from different taxonomic groups spread across different trophic guilds and respond to changes on resource availability and to impacts of environmental disturbances, in time or space (BARETTA; BROWN; CARDOSO, 2010; BARTZ et al., 2014). Thus, studies with this approach are still necessary, in order to identify defined response patterns of soil fauna to different treatments for recovery degraded areas.

Information on the recovering of areas of gravel extraction of the Caatinga biome are scarce (RESENDE; CHAER, 2010; LIMA et al., 2015), and no data on the monitoring of these areas through the soil fauna. Thus, the objective of this work was to assess the soil fauna as bioindicator of soil quality, evaluating areas with addition of topsoil (WAT) and control areas (CWT) without the addition of topsoil, used for forest plantations implemented for recovering gravel extraction areas, in the State of Rio Grande do Norte, Brazil.

\section{MATERIAL AND METHODS}

The experiment was conducted in the mesoregion west of the State of Rio Grande do Norte (RN), from March, 2008 in areas of relatively flat terrain. The region climate is BSh, i.e., dry and very hot (KÖPPEN, 1948), with two well defined seasons, rainy (February to May) and dry (June to January) (CARMO FILHO; ESPÍNOLA SOBRINHO; MAIA NETO, 1991). The region predominant soil type is Oxisol (eutrophic Yellow Latosol - SiBCS) (SANTOS et al., 2013) and the original vegetation was typical of the Caatinga biome (VELOSO; RANGEL FILHO; LIMA, 1991).

Three gravel extraction areas with depleted mines was selected, considering each one as a repetition, in the area of the Exploitation and Production Operation Unit of the States of Rio Grande do Norte and Ceará (UO-RNCE; Petrobras Inc.). The Site 1 was located in Assú RN (DJ-118-1; UTM 24M 9401656.33E/733895.43S) and the Site 2 (SJ-155; UTM 24M 9414244.59E/755907.98S) and Site $\quad 3 \quad$ (ZJ-111-2; $\quad$ UTM $24 M$ 9418219.06E/768376.11S) in Pendências RN. A neighboring area to each site, covered with native forest, was used as reference (NFC), thus the NFC were evaluated with three replications. The attributes of the topsoil $(0-5 \mathrm{~cm})$ of these three areas were assessed by Lima (2012) and their average values are shown in Table 1.

A randomized block experimental design in a split-plot arrangement was used, with one block of $20 \times 40 \mathrm{~m}$ divided in two adjacent plots $(20 \times 40 \mathrm{~m})$ in each replication, which was subjected to the different treatments. The treatments consisted of areas with addition of topsoil (WAT), i.e., with application of a layer of $20 \mathrm{~cm}$ of soil in their surface, and control areas (CWT) without the addition of topsoil.

The topsoil used was from excavations of new gravel mines or oil wells installations. Seedlings of 20 tree and shrub species from different families were planted in the plots, which included 13 native Caatinga species and seven exotic species. The tree species were arranged in a single row spaced $2 \mathrm{~m}$ apart, and the species had the same occurrence in the treatments.

The seedlings were grown in the plant nursery of the Federal Rural University of Semi-Arid (UFERSA), in a substrate prepared with subsurface soil and an organic compound $\left(2: 1 \mathrm{~V} \mathrm{v}^{-1}\right)$. The legume species capable of nodulating were 
inoculated with rhizobia strains and arbuscular mycorrhizal fungi (AMF) from the Embrapa Agrobiologia (Seropédica RJ), according to the method described by Resende et al. (2010). The other tree species were inoculated only with AMF.
The plants had heights of 30 to $50 \mathrm{~cm}$ at planting. The plantations were enclosed with fences, to prevent the entry of animals. The seedlings were not irrigated during the experiment.

Table 1. Average values of the topsoil attributes $(0-5 \mathrm{~cm})$ in areas with addition of topsoil (WAT), control areas without the addition of topsoil (CWT) and native forests of the Caatinga biome (NFC). State of Rio Grande do Norte, Brazil.

\begin{tabular}{lrrr}
\hline \multicolumn{1}{c}{ Attributes } & CWT & WAT & NFC \\
\hline $\mathrm{BD}\left(\mathrm{g} \mathrm{cm}^{-3}\right)$ & 1.43 & 1.42 & 1.54 \\
$\mathrm{pH}$ & 5.72 & 7.99 & 6.72 \\
$\mathrm{TOC}(\%)$ & 0.53 & 1.09 & 0.95 \\
$\mathrm{~N}(\%)$ & 0.04 & 0.10 & 0.07 \\
$\mathrm{P}\left(\mathrm{mg} \mathrm{L}^{-1}\right)$ & 1.55 & 2.04 & 6.11 \\
$\mathrm{~K}\left(\mathrm{mg} \mathrm{L}^{-1}\right)$ & 60.00 & 128.00 & 90.00 \\
$\mathrm{Ca}\left(\mathrm{cmol}_{\mathrm{c}} \mathrm{dm}^{-3}\right)$ & 4.50 & 8.05 & 3.30 \\
$\mathrm{Mg}\left(\mathrm{cmol}_{\mathrm{c}} \mathrm{dm}^{-3}\right)$ & 3.12 & 3.96 & 16.94 \\
$\mathrm{Al}\left(\mathrm{cmol}_{\mathrm{c}} \mathrm{dm}^{-3}\right)$ & 0.49 & 0.01 & 0.03 \\
$\mathrm{H}+\mathrm{Al}\left(\mathrm{cmol}_{\mathrm{c}} \mathrm{dm}^{-3}\right)$ & 2.91 & 0.50 & 1.96 \\
\hline
\end{tabular}

${ }^{1}$ Average values from 06 replications. SD = soil density (undeformed samples); $\mathrm{TOC}=$ total organic carbon

The plant species were chosen according to the seed availability at the experiment implementation (Table 2). Besides, the exotic species were also selected considering those that showed good growth in previous studies on revegetation of degraded tropical areas by the removal of the surface horizons (FRANCO; FARIA, 1997; MACEDO et al., 2008; RESENDE et al., 2013).

The effects of the treatments (WAT and CWT) on the soil fauna community were evaluated and compared with the NFC. Thus, 10 pitfall traps spaced $5 \mathrm{~m}$ apart were placed in a $50-\mathrm{m}$ diagonal transect designed in each plot and NFC. The traps consisted of $500-\mathrm{mL}$ plastic pots containing approximately $300 \mathrm{ml}$ of a formaldehyde solution (4\%), which remained in the field for seven consecutive days. Samples of the soil fauna were collected at the end of the rainy season (July) of
2008, shortly after the beginning of the experiment, 2009, 2011 and 2014, i.e., at 0, 1, 3 and 6 years after the experiment implementation.

The content collected in the traps was passed through a $0.053-\mathrm{mm}$ mesh sieve using a wash bottle with distilled water. The retained content was put in Petri dishes, and the organisms were identified and quantified by taxonomic group (order, class, family) (CSIRO, 1991) using a binocular loupe. Organisms from the Formicidae family were considered as a taxonomic group (Hymenoptera), since they are easily identified. The Collembola class was divided into three different orders (Entomobryomorpha, Poduromorpha and Symphypleona). Adult specimens were separated from larval forms, due to their different ecological functions in the soil environment, even when they were from the same taxonomic group.

Table 2. Tree and shrub species chosen for recovery of degraded areas by gravel extraction in Rio Grande do Norte, Brazil.

\begin{tabular}{|c|c|c|c|}
\hline Family & Species & $\begin{array}{c}\text { Nodulating } \\
\text { species }\end{array}$ & $\begin{array}{c}\text { Non-nodulating } \\
\text { species }\end{array}$ \\
\hline \multirow[t]{2}{*}{ Anacardiaceae } & Myracrodruon urundeuva Allemão & - & $\mathrm{X}$ \\
\hline & Schinus terebinthifolius Raddi.* & - & - \\
\hline Apocynaceae & Aspidosperma pyrifolium Mart. & - & $\mathrm{X}$ \\
\hline \multirow[t]{2}{*}{ Bignoniaceae } & Tabebuia caraiba (Mart.) Bureau & - & $\mathrm{X}$ \\
\hline & Tabebuia impetiginosa Mart. ex. DC. & - & $\mathrm{X}$ \\
\hline \multirow[t]{3}{*}{ Leguminosae/ Caesalpinioideae } & Parkinsonia aculeata $\mathrm{L}$. & $\mathrm{X}$ & \\
\hline & Caesalpinia bracteosaTul. & - & $\mathrm{X}$ \\
\hline & Caesalpinia ferrea Mart. Extul. & - & $\mathrm{X}$ \\
\hline \multirow[t]{2}{*}{ Leguminosae/ Faboideae } & Gliricidia sepium (Jacq.) Kunth ex. Walp.* & $\mathrm{X}$ & - \\
\hline & Amburana cearensis (Allemão) A. C. Sm. & - & $\mathrm{X}$ \\
\hline \multirow[t]{6}{*}{ Leguminosae/ Mimosoideae } & Enterolobium timbouva Mart. & $\mathrm{X}$ & \\
\hline & Erythrina velutina Willd. & $\mathrm{X}$ & \\
\hline & Mimosa tenuiflora (Willd.) Poir. & $\mathrm{X}$ & \\
\hline & Mimosa caesalpiniifoliaBenth. & $\mathrm{X}$ & \\
\hline & Vachellia farnesiana (L.) Wight \&Arn. & $\mathrm{X}$ & $\mathrm{X}$ \\
\hline & Acacia angustissima (Mill.) Kuntze* & $\mathrm{X}$ & - \\
\hline
\end{tabular}

*Exotic plant species of the Caatinga. Source: Species List from Flora of Brazil. Available at: http:// floradobrasil.jbrj.gov.br/jabot/listaBrasil/PrincipalUC/PrincipalUC.do?lingua=PT. 
K. D. R. LIMA et al.

Table 2. Continuation.

\begin{tabular}{|c|c|c|c|}
\hline Family & Species & $\begin{array}{c}\text { Nodulating } \\
\text { species }\end{array}$ & $\begin{array}{c}\text { Non-nodulating } \\
\text { species }\end{array}$ \\
\hline & Calliandra selloi (Spreng.) J. F. Macbr.* & $\mathrm{X}$ & - \\
\hline & Pseudosamanea guachapele (Kunth) Harms* & $\mathrm{X}$ & - \\
\hline & Adenanthera pavonina $\mathrm{L}^{*}$ & - & $X-$ \\
\hline Meliaceae & Azadirachta indica A. Juss.* & - & $\mathrm{X}-$ \\
\hline
\end{tabular}

*Exotic plant species of the Caatinga. Source: Species List from Flora of Brazil. Available at: http:// floradobrasil.jbrj.gov.br/jabot/listaBrasil/PrincipalUC/PrincipalUC.do?lingua=PT.

Subsequently, the organisms were stored in Eppendorf containing an alcohol solution (70\%). The total abundance and abundance of the taxonomic groups (specimens $\operatorname{trap}^{-1}$ day $^{-1}$ ) was calculated by dividing the average number of specimens per trap by the number of days that the traps remained in the field (CAMARA; CORREIA; VILLELA, 2012). The relative share $(\%)$ of each taxonomic group was calculated using their abundance and the total abundance. The taxonomic groups with less than $2 \%$ of relative share were classified as Others. The community richness ( $\mathrm{R}$; total number of groups), uniformity (U; Pielou index) and diversity $(\mathrm{H}$; Shannon index) was estimated according to the formulas described by Odum (1988).

The V Index (Change Index) was used to assess possible changes in the abundance and activity of the soil fauna community depending on the effect of each treatment (WARDLE, 1995). This index was calculated by the equation: $\mathrm{V}=[(2 \mathrm{x} / \mathrm{x}+\mathrm{y})-1]$, where $\mathrm{x}=$ abundance of groups in each treatment (CWT and WAT); $y=$ abundance of groups in the reference area (NFC). The V index ranges from -1 to 1 and the closer this index is to 1 , the greater the abundance of the soil fauna groups was stimulated by the treatments. On the other hand, the closer this index is to -1 , the greater the abundance was inhibited. Values between -0.05 and 0.05 indicate that the abundance was not affected by the treatments compared with the original or ideal situation. According to the values found, the effect of the treatments on abundance of groups was classified in categories, as shown in Table 3.

Table 3. Categories of inhibition and stimulation of soil fauna taxonomic groups in response to intervention processes, based on the V index (modified from WARDLE, 1995).

\begin{tabular}{lcc}
\hline \multicolumn{1}{c}{ Category } & Symbol & Index V \\
\hline Extreme inhibition & EI & $\mathrm{V}<-0.67$ \\
Moderate inhibition & MI & $-0.33>\mathrm{V}<-0.67$ \\
Slight inhibition & SI & $-0.05>\mathrm{V}<-0.33$ \\
No change & NC & $-0.05>\mathrm{V}<0.05$ \\
Slight stimulation & SS & $0.05>\mathrm{V}<0.33$ \\
Moderate stimulation & MS & $0.33>\mathrm{V}<0.67$ \\
Extreme stimulation & ES & $\mathrm{V}>0.67$ \\
\hline
\end{tabular}

The effect of treatments (CWT, WAT) and NFC was compare, considering the replication of each collection time, using univariate statistical analysis. Thus, the total abundance values were subjected to analysis of variance, and averages were compared using the nonparametric Kruskal-Wallis test $(p<0.05)$, using the software BioEstat 5.3 (Mamirauá Institute, Belém). Hierarchical clustering analysis was used to identify the possible relation patterns between the treatments (WAT and CWT) effects in the forest plantations on the soil fauna community and NFC. A dendrogram of similarity was developed by the Bray-Curtis distance, based on the single linkage method, considering the data of community average abundance of the areas in each year evaluated, using the software PAST $2.17 \mathrm{c}$ (HAMMER; HARPER; RYAN, 2001).

\section{RESULTS AND DISCUSSION}

The soil fauna organisms captured $(45,740)$, were from 36 taxonomic groups, from which 27 $(75 \%)$ presented general occurrence, i.e., were found in the treatments (CWT and WAT) and in the NFC. On the other hand, nine groups $(25 \%)$ presented restrict occurrence. Mantodea and Pseudoscorpionida specimens were found only in the WAT; Opilionida in the CWT; and Dermaptera in the CWT and WAT (all these groups include predator organisms). Adult Trichoptera (predators and herbivores) were found only in the NFC and WAT. Blattodea (saprophagous), Embioptera (herbivores and saprophagous), Trichoptera larvae (predators and saprophagous) and Nematodea (mostly microphagous) occurred only in the NFC.

The response of the soil fauna community to the treatments, regarding the structural variables 
(richness, diversity, uniformity and abundance), was widely varied. However, certain response patterns were identified. Overall, the community richness was higher in the NFC, compared with the treatments, while the CWT and WAT present similar richness values (Figure 1). The average values of diversity were higher in the NFC, compared with the WAT and CWT, and higher in CWT compared with WAT (Figure 2).

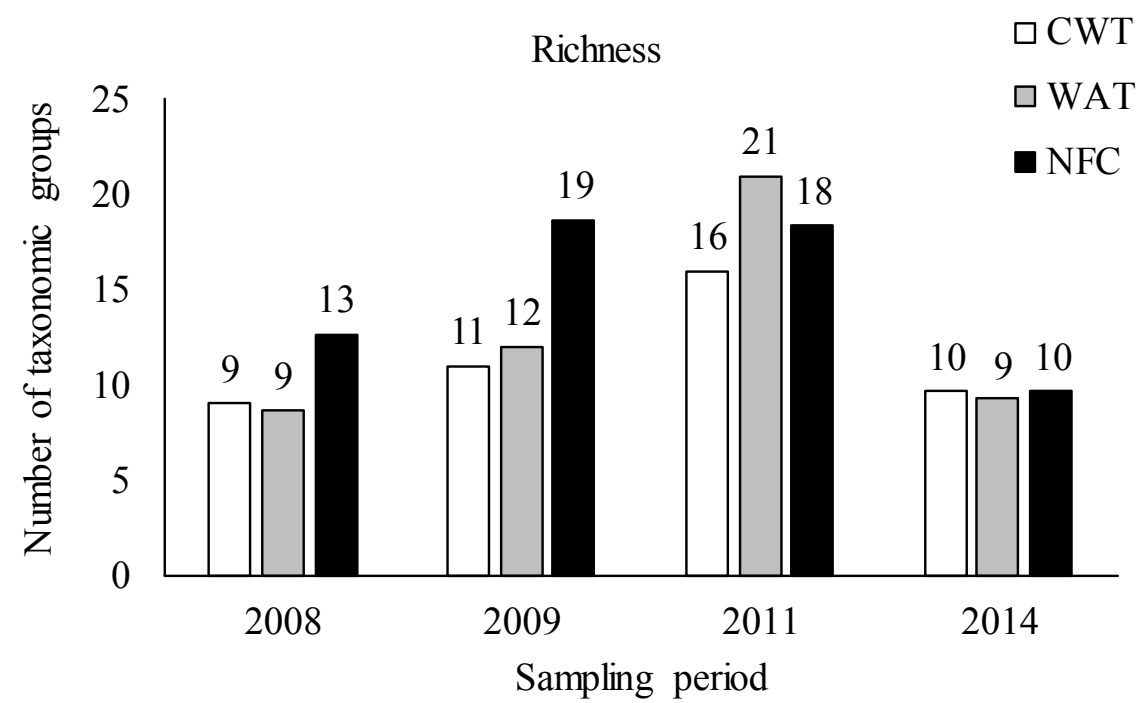

Figure 1. Soil fauna richness in forest plantations, used for recovery of areas degraded by gravel extraction, in areas with addition of topsoil (WAT), control areas without the addition of topsoil (CWT) and native forests of the Caatinga biome (NFC). State of Rio Grande do Norte, Brazil. Average values from three replications per collection time.

The largest number of taxonomic groups representing the greatest diversity of trophic guilds was found in the NFC, among the groups with restricted occurrence, generating greater richness and diversity of soil fauna community in this area, compared with the treatments CWT and WAT (Figures 1 and 2). In general, the richness of the WAT was higher, compared with the CWT.

\section{Diversity}

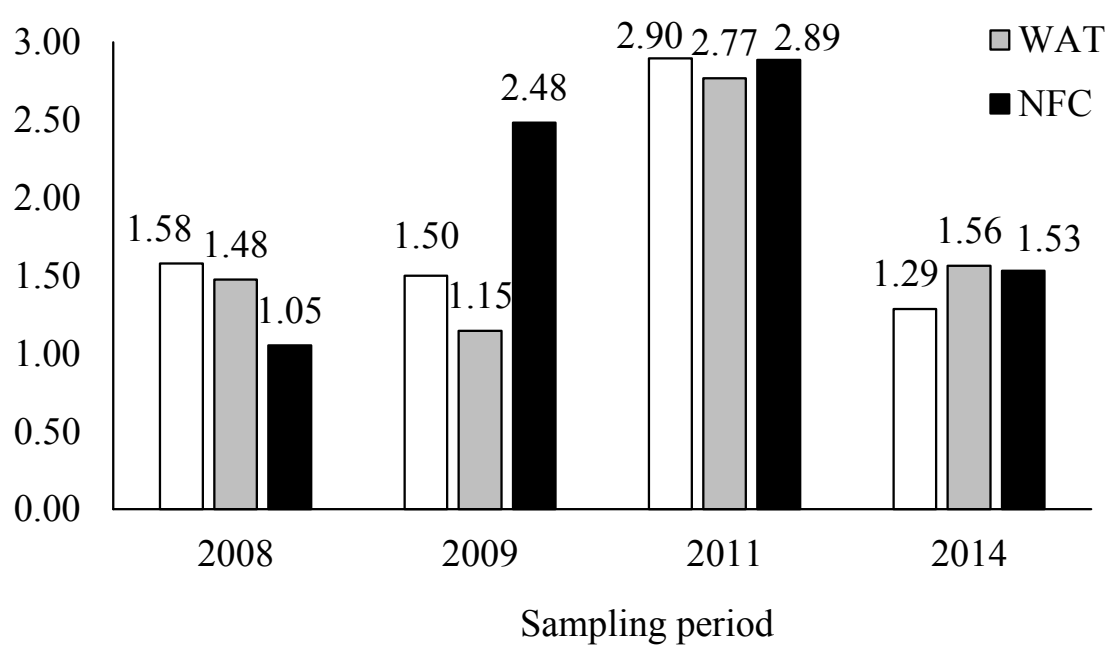

Figure 2. Soil fauna diversity in forest plantations, used for recovery of areas degraded by gravel extraction, in areas with addition of topsoil (WAT), control areas without the addition of topsoil (CWT) and native forests of the Caatinga biome (NFC). State of Rio Grande do Norte, Brazil. Average values from three replications per collection time.

Two response patterns of community uniformity to the soil treatments and NFC were found. The uniformity average values were higher in the NFC compared with WAT, and higher in the WAT compared with CWT (Figure 3). The uniformity is used to evaluate the distribution of specimens into taxonomic groups. This index, as well as the richness, affects the community diversity values. Thus, even if the richness is high, the predominance of one or few groups in the community decreases the uniformity and diversity values.

Therefore, the diversity was higher in the NFC compared with WAT because its richness and 
uniformity were higher (Figures 1 to 3 ). The lower value of diversity of the WAT compared with CWT, was due to its lower uniformity, since the WAT treatment had predominance of Entomobryomorpha, whose relative share accounted for more than half of its total community (Figure 4). The CWT treatment also presented predominance of only one group, Formicidae, however, the magnitude of its share was lower compared to that of the predominant group in WAT (Entomobryomorpha).

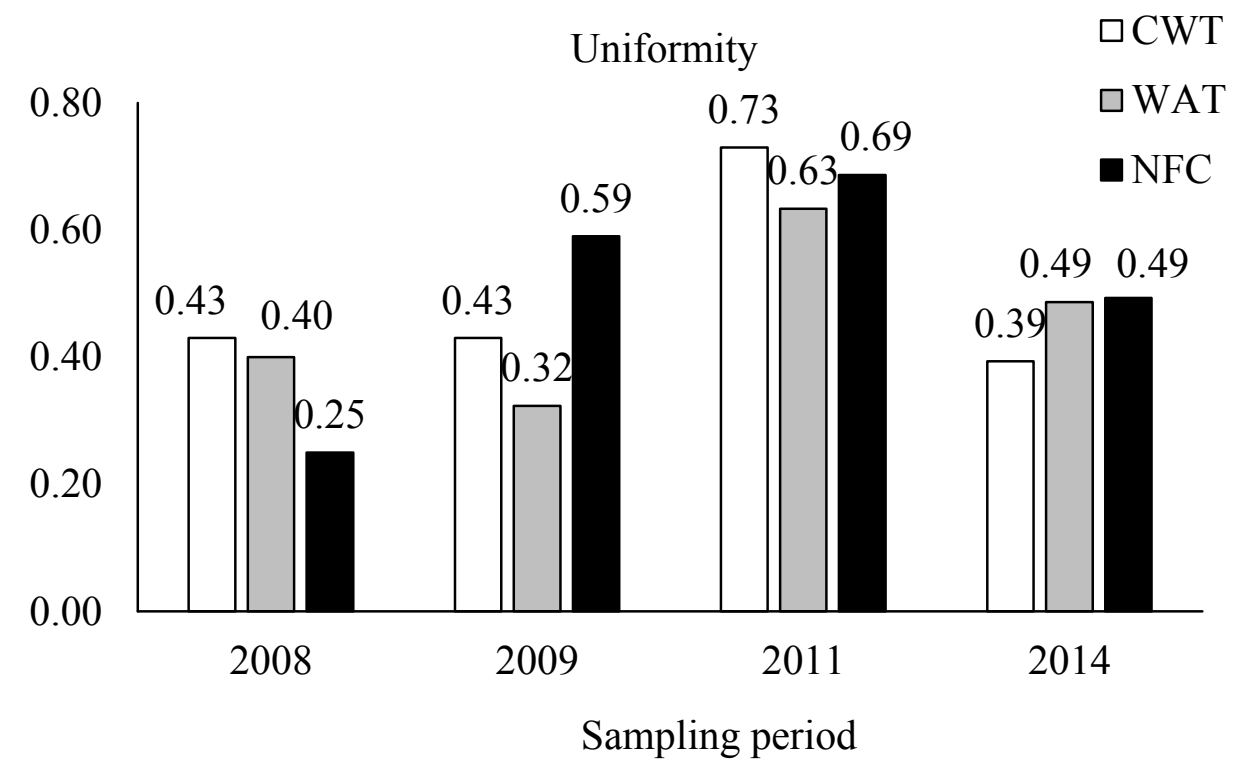

Figure 3. Soil fauna uniformity in forest plantations, used for recovery of areas degraded by gravel extraction, in areas with addition of topsoil (WAT), control areas without the addition of topsoil (CWT) and native forests of the Caatinga biome (NFC). State of Rio Grande do Norte, Brazil. Average values from three replications per collection time.

Greatest values of richness, diversity and uniformity in the NFC, compared with CWT and WAT, were expected, since the greater ecological complexity of its soil fauna community was probably due to the greater structure and diversity of the plant community in this area, compared with the forest plantations. This pattern in terms of the soil fauna community was also observed in the Caatinga biome (NUNES et al., 2012) and in Atlantic Forest fragments (CAMARA; CORREIA; VILLELA, 2012; CUNHA NETO et al., 2012). Plant communities with greater arboreal structure result in greater canopy closure, litterfall production and thickness of the litterfall layer on the forest soil surface (NEGRETE-YANKELEVICH et al., 2006).

Moreover, the greatest plant diversity contributes to the production of a more heterogeneous litterfall (CORREIA; ANDRADE, 2008), which generates more favorable microclimate conditions for the reproduction and survival of soil fauna organisms, whose community presents greater diversity due to the availability of a wider range of niches to be colonized (SZINWELSKI et al., 2012; PEREIRA et al., 2013).

Saprophagous and microphagous organisms are directly related to the processes of decomposition and mineralization of the organic matter (LAVELLE, 1996; NEHER, 2001), whereas predators have high-energy requirements (BEGON;
TOWNSEND; HARPER, 2005). Thus, these trophic guilds are important for the ecological functioning of the ecosystems and, therefore, can be used as biological indicators of environmental quality.

According to the averages of the four evaluation times, the total richness values were 11 (CWT), 13 (WAT) and 15 (NFC); the diversity values were 1.82 (CWT), 1.74 (WAT) and 1.99 (NFC); and the uniformity were 0.50 (CWT), 0.46 (WAT) and 0.51 (NFC).

The soil fauna community showed, in general, greater structural complexity than that found by NUNES et al. (2008) in the State of Ceará, who used the same evaluation timing. These authors compared two areas of Caatinga that were cleared and their vegetation were burned, with subsequent intercropping of maize and beans (two years), and four (A1) and five years (A2) of fallow, with a forest area of approximately 50 years (A3). They found average richness of 10 (A1), 9 (A2) and 11 (A3), diversity of 1.04 (A1), 1.56 (A2) and 1.12 (A3), and uniformity of 0.30 (A1), 0.49 (A2) and 0.32 (A3).

The soil fauna community also showed, in general, greater structural complexity than that found by SOUTO et al. (2008), who found smaller diversity values in a preserved area of Caatinga in the state of Paraiba, in July in the years 2004 (1.18) and 2005 (1.35). However, they found higher uniformity values, 0.71 (2004) and 0.82 (2005). 
K. D. R. LIMA et al.

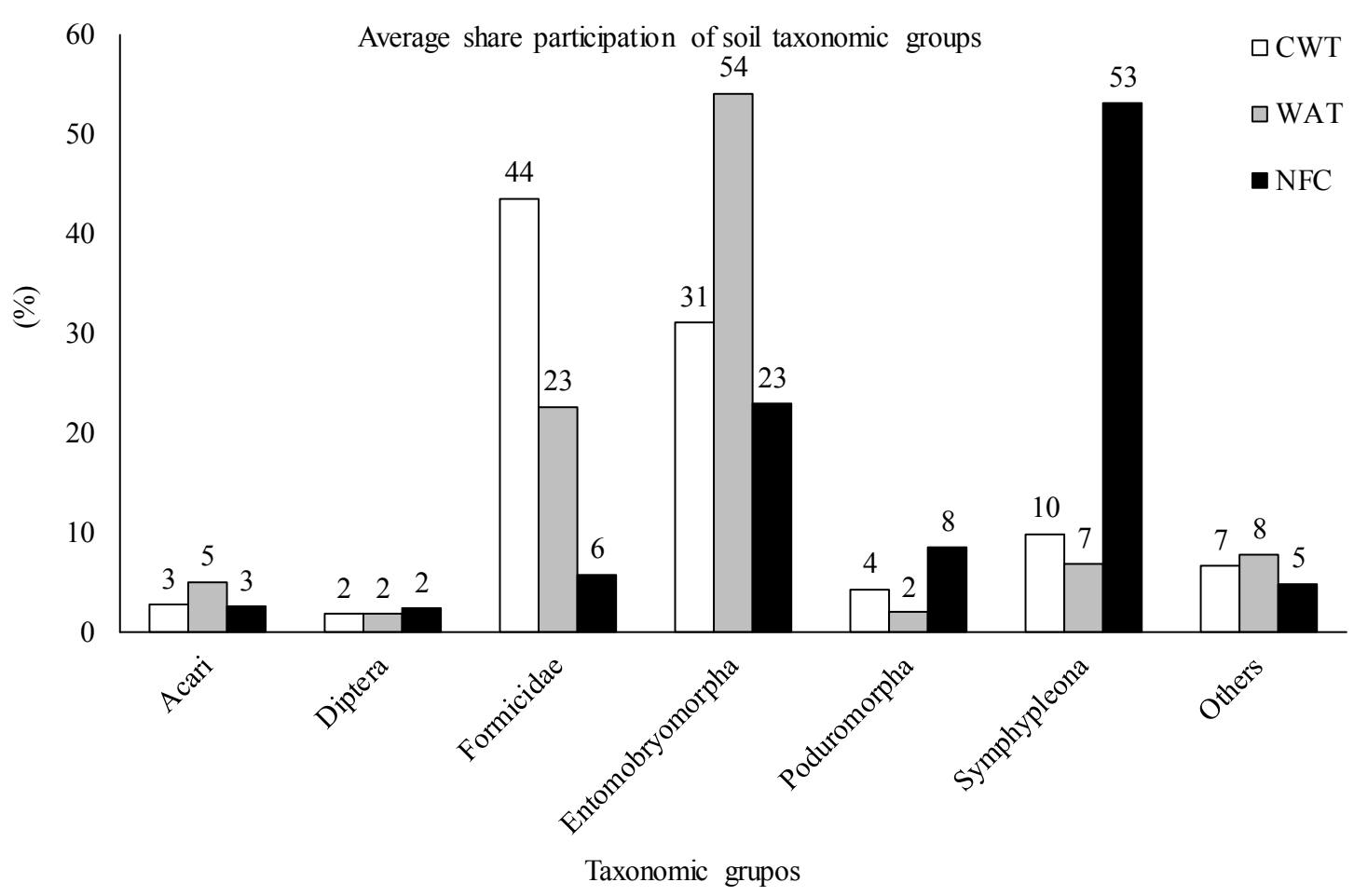

Figure 4. Average share percentage of soil fauna community groups in forest plantations, used for recovery of areas degraded by gravel extraction, in areas with addition of topsoil (WAT), control areas without the addition of topsoil (CWT) and native forests of the Caatinga biome (NFC). State of Rio Grande do Norte, Brazil.

Mata-dos-Cocais is a transition vegetation area of the Caatinga, Cerrado and Amazon biomes in the state of Piauí, where NUNES et al. (2012) evaluated leucaena (Leucaena leucocephala (Lam.) de Wit.) crops in the rainy season, and found greater richness (18 in both ecosystems), diversity (3.01 and 2.80 , respectively) and uniformity (0.72 and 0.68 , respectively).

Six taxonomic groups (14\%), Acari, Diptera (adults), Entomobryomorpha, Formicidae, Poduromorpha and Symphypleona, represented 93 (CWT), 92 (WAT) and 95\% (NFC) of all organisms of the soil fauna captured (Figure 4). According to Souto et al. (2008), the most abundant groups in preserved areas (Caatinga) are the Acari, Coleoptera, Collembola, Diptera and Hymenoptera. On the other hand, Nunes, Araujo Filho; Menezes (2009) evaluated a similar ecosystem and found greater abundance of Araneae and Coleoptera.

The relative share of the Formicidae varied, which was higher in the CWT and lower in the NFC. The relative share of the Entomobryomorpha was higher in the WAT and lower in the NFC. The relative share of the Poduromorpha and Symphypleona was higher in the NFC and lower in the WAT (Figure 4). Thus, the areas presented different community composition.

Some authors reported greater percentage share of Formicidae in environments of higher human impact, such as in areas in early stages of succession (CAMARA; CORREIA; VILLELA, 2012), as well as in edges of forest fragments compared to its interior (PEREIRA et al., 2013).
Nunes, Araujo Filho; Menezes (2009) evaluated different soil management systems in preserved areas (Caatinga) and found higher number of Formicidae in the area with vegetation subjected to burned and subsequent intercropping of maize and beans, in the first year of cultivation compared to a native forest.

The relative share of the Collembola group (Entomobryomorpha, Poduromorpha and Symphypleona) was 45 (CWT), 63 (WAT) and 84\% (NFC). Similar results were found by Nunes, Araujo Filho and Menezes, (2009), who found the greater share for the Collembola group in the Caatinga area (control), compared with managed treatments.

These results suggest that the greater contribution of the Formicidae group is related to lower stability or more affected systems; and the opposite seems to occur for the Collembola group, whose share may be greater on more stable or less impacted systems. The other taxonomic groups, classified as Others (percentage share $<2 \%$ ) encompassed the groups Araneae, Auchenorrhyncha, Blattodea, Chilopoda, Coleoptera (larvae and adults), Dermaptera, Diplopoda, Diplura, Embioptera, Gastropoda, Heteroptera, Hymenoptera, Isopoda, Isoptera, Lepidoptera (larvae and adults), Mantodea, Nematodea, Opilionida, Orthoptera, Pseudoscorpionida, Psocoptera, Scorpionida, Sternorrhyncha, Thysanoptera, Thysanura, Trichoptera (larvae and adults) and larvae of Diptera. The total abundance of the soil fauna community in 2008 were significantly greater $(\mathrm{p}<0.05)$ in the NFC, compared with CWT and WAT, which had similar results (Figure 5). In 2009, 
was greater in the WAT compared with the CWT and NFC, which had similar results. In 2011, was greater in the WAT, compared with CWT, and these two treatments were similar to the NFC. In 2014, no significant differences among the treatments and NFC were found.

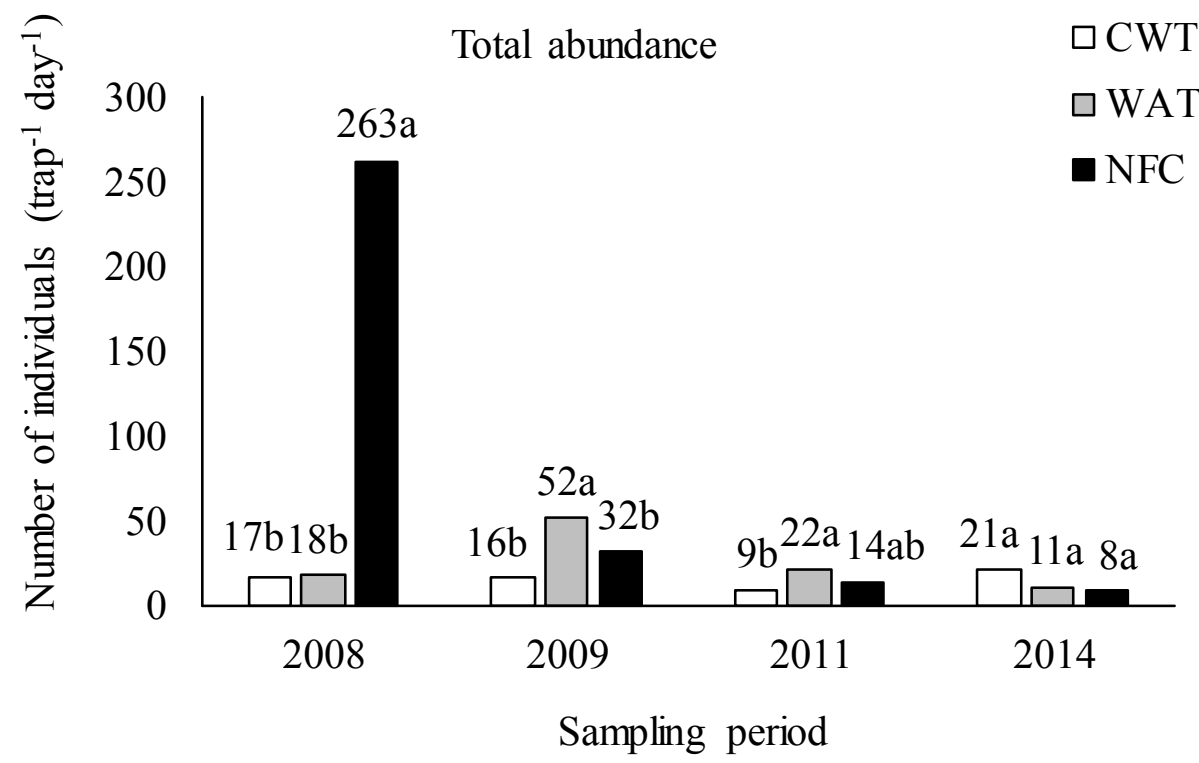

Figure 5. Total abundance of soil fauna in forest plantations, used for recovery of areas degraded by gravel extraction, in areas with addition of topsoil (WAT), control areas without the addition of topsoil (CWT) and native forests of the Caatinga biome (NFC). State of Rio Grande do Norte, Brazil. Average values from three replications per collection time. Averages followed by different letters comparing the WAT, CWT and NFC within the same collection time, were significant different by the Kruskal-Wallis non-parametric test at $5 \%$ of significance.

All categories of the $\mathrm{V}$ index were found for the soil fauna groups in the WAT treatment, while for the CWT only the moderate stimulation (MS) was not found (Figure 6). The abundance of $75 \%$ of the groups in CWT and $69 \%$ of the groups in WAT presented some type of inhibition. The extreme inhibition (EI; 42\%) was predominant in the CWT, followed by the moderate inhibition (MI; 28\%). The EI and MI was predominant in the WAT, both expressing the same magnitude $(25 \%)$.

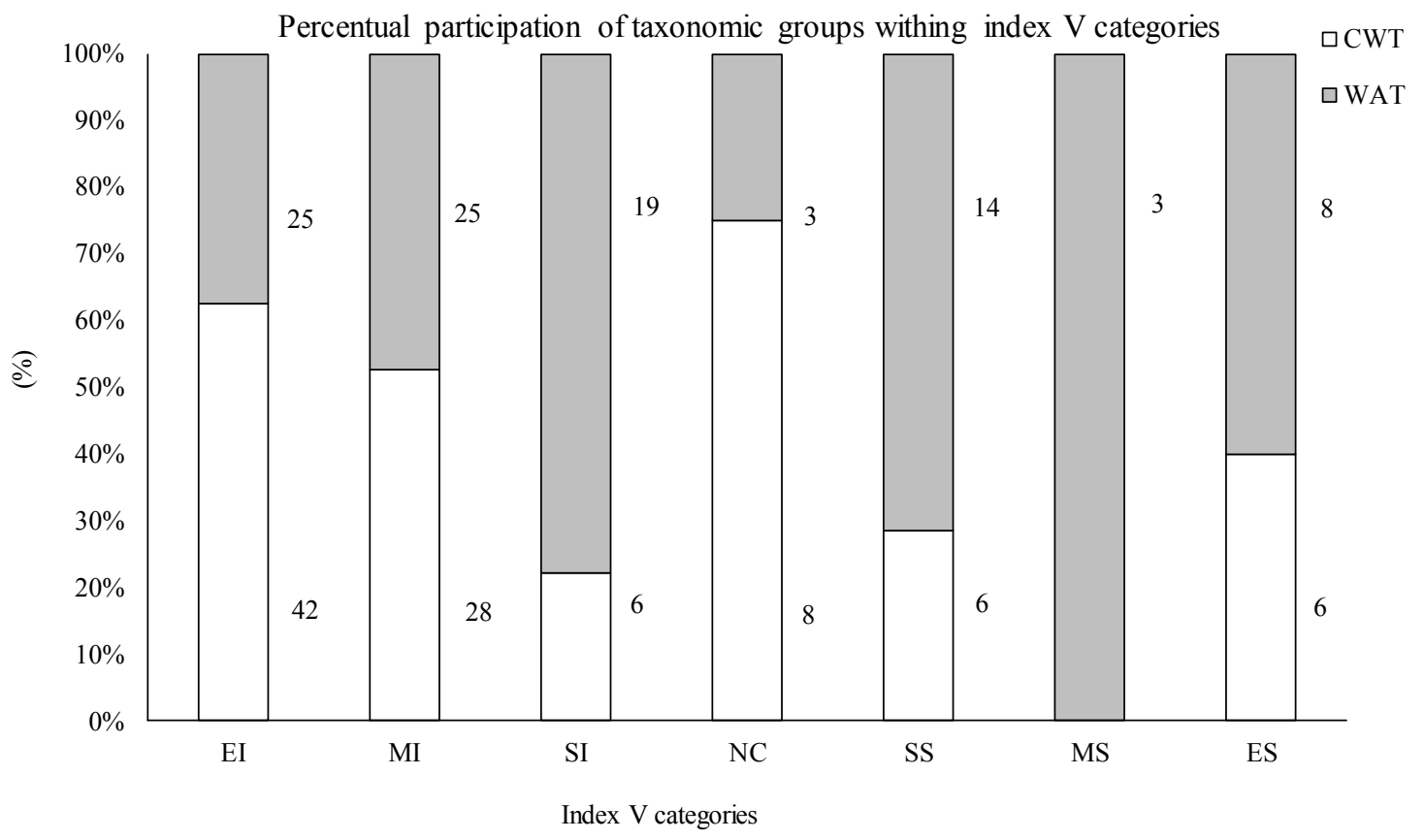

Figure 6. V index of soil fauna in forest plantations, used for recovery of areas degraded by gravel extraction, in areas with addition of topsoil (WAT) and control areas without the addition of topsoil (CWT). State of Rio Grande do Norte, Brazil. $\mathrm{EI}=$ extreme inhibition; $\mathrm{MI}=$ moderate inhibition; SI: slight inhibition; $\mathrm{NC}=$ no change; $\mathrm{SS}=$ slight stimulation; $\mathrm{MS}=$ moderate stimulation; $\mathrm{ES}=$ extreme stimulation . 
Consequently, the abundance of a higher percentage of the soil fauna groups was somewhat stimulated in the WAT $(25 \%)$ with predominance of slight (SS; 14\%) and extreme stimulation (ES; 8\%), compared with the CWT, in which only $12 \%$ of the groups had their abundance somewhat stimulated, of which $6 \%$ had LS or ES (Figure 6).

According to the hierarchical cluster diagram (Figure 7), the treatments CWT and WAT were relatively distant from each other (around 0.60) and formed a group that showed comparatively low similarity (distance of approximately 0.35 ) compared with the NFC. This pattern confirmed the results found by comparing the averages (univariate analysis), indicating that the WAT treatment was more favorable to the soil fauna, compared with the CWT. However, even six years after the implementation of the treatments (CWT and WAT), they were not able to restore the abundance of the soil fauna community found in the NFC.

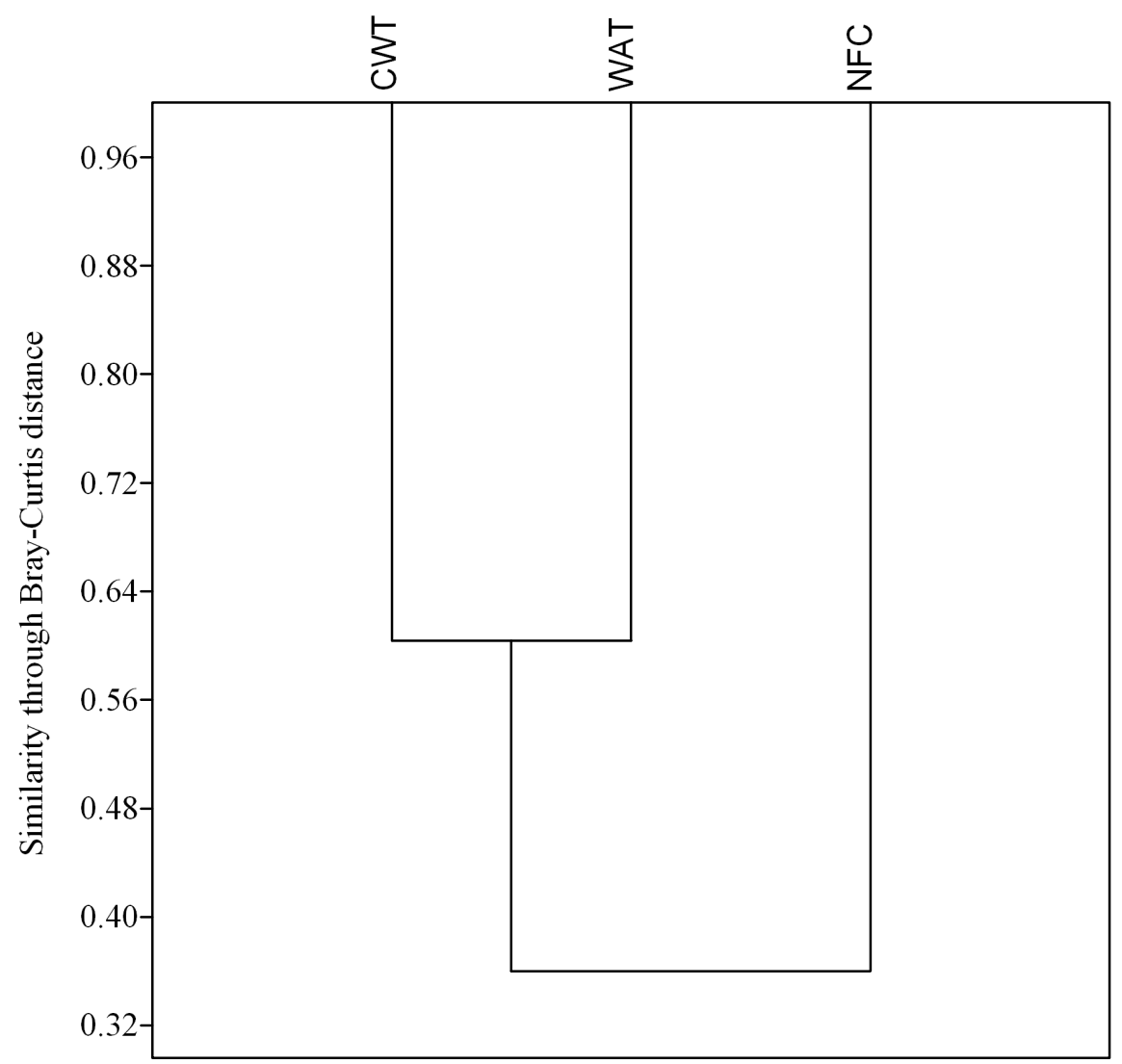

Figure 7. Dendrogram of similarity found by the average abundance of soil fauna community in forest plantations used for recovery of areas degraded by gravel extraction, in areas with addition of topsoil (WAT), control areas without the addition of topsoil (CWT) and native forests of the Caatinga biome (NFC). State of Rio Grande do Norte, Brazil.

Considering only the richness and abundance analysis, the conditions in the WAT were more favorable to the soil community, compared with CWT, throughout the chronological gradient (Figures 1 and 5). Moreover, six years after the implementation of the experiment, the values of these variables in the CWT and WAT approached the values found in the NFC.

Therefore, according to these results and considering the diversity and uniformity variables, the NFC and WAT were more favorable to the soil community, compared with CWT in 2014 (Figures 2 and 3). Combining this information to those presented in Figures 4, 6 and 7, the results showed that the WAT had a positive impact on the soil community compared with the CWT, despite the WAT soil community had not reached the characteristics found in the NFC.

\section{CONCLUSIONS}

The soil fauna was efficient as a bioindicator for monitoring the ecological quality of the areas evaluated in the Caatinga biome.

The ecological complexity of the soil fauna in the areas of native forest of Caatinga was higher than that found in the forest plantations, regardless of the addition of topsoil.

The addition of topsoil in forest plantations used for recovering degraded Caatinga areas is recommended, since this practice had a positive impact on the soil fauna community, compared with areas without the addition of topsoil. 


\section{ACKNOWLEDGEMENTS}

The authors thank the Federal Rural University of Semi-Arid, Rural Federal University of Rio de Janeiro and Embrapa Agrobiology for the infrastructure; the CAPES for granting a research scholarship to the first author; and José Erivaldo de Araújo, Jeane Cruz Portela, Diana Freitas, Carlos Fernando Cunha, Marcelo Antoniol, Cid Rodrigo Cavalcanti de Azevedo, Roberto Oliveira, Sandra Lima, Raul Farias, Augusto Neto, Eloísa Benazzi and Fernanda Camilo for their support during the experiment conduction and data analysis.

\section{REFERENCES}

BARETTA, D.; BROWN, G. G.; CARDOSO, E. J. B. N. Potencial da macrofauna e outras variáveis edáficas como indicadores da qualidade do solo em áreas com Araucaria angustifolia. Acta Zoológica Mexicana, Xalapa, v. 26, n. 2, p. 135-150, 2010.

BARTZ, M. L. C. et al. The influence of land use systems on soil and surface litter fauna in the western region of Santa Catarina. Revista Ciência Agronômica, Fortaleza, v. 45, n. 5, p. 880-887, 2014.

BATISTA, Q. R. et al. Bioqualidade de área degradada pela extração de argila, revegetada com Eucalyptus spp. e sabiá. Revista Caatinga, Mossoró, v. 21, n. 1, p. 169-178, 2008.

BEGON, M.; TOWNSEND, C. R.; HARPER, J. L. Ecology: from individuals to ecosystems. Malden: Blackwell Publishing, 2005. 738 p.

CAMARA, R.; CORREIA, M. E. F.; VILLELA, D. M. Effects of eucalyptus plantations on soil arthropod communities in a Brazilian Atlantic Forest conservation. Bioscience Journal, Uberlândia, v. 28, n. 3, p. 445-455, 2012.

CARMO FILHO, F.; ESPÍNOLA SOBRINHO, J.; MAIA NETO, J. M. Dados climatológicos de Mossoró: um município semi-árido nordestino. Mossoró, RN: UFERSA, 1991. 121 p. (Coleção Mossoroense, C. 30).

COMMONWEALTH SCIENTIFIC AND INDUSTRIAL RESEARCH ORGANIZATION CSIRO. The insects of Australia: a textbook for students and research workers. 2 ed. New York: Cornell University Press, 1991. v. 1 and 2. 1137 p.

CORREIA, M. E. F.; ANDRADE, A. G. Formação de serapilheira e ciclagem de nutrientes. In: SANTOS, G. A., CAMARGO, F. A. O. (Eds.).
Fundamentos da matéria orgânica do solo: ecossistemas tropicais e subtropicais. Porto Alegre, RS: Gênesis, 2008. p. 137-170.

CUNHA NETO, F. V. et al. Soil fauna as an indicator of soil quality in forest stands, pasture and secondary forest. Revista Brasileira de Ciência do Solo, Viçosa, v. 36, n. 5, p. 1407-1417, 2012.

FERREIRA, W. C. et al. Regeneração natural como indicador de recuperação de área degradada a jusante da usina hidrelétrica de Camargos, MG. Revista Árvore, Viçosa, v. 34, n. 4, p. 651-660, 2010.

FRANCO, A. A.; FARIA, S. M. The contribution of $\mathrm{N}_{2}$-fixing tree legumes to land reclamation and sustainability in the tropics. Soil Biology \& Biochemistry, Great Britain, v. 29, n. 5-6, p. 897-903, 1997.

HAMMER, Ø.; HARPER, D. A. T.; RYAN, P. D. PAST: Paleontological statistics software package for education and data analysis. Palaeontologia Electronica, California, v. 4, n. 1, p. 1-9, 2001.

KÖPPEN, W. Climatologia: conunestudio de los climas de laTierra. Mexico: Fondo de Cultura Economica, 1948. 478 p.

LAVELLE, P. Diversity of soil fauna and ecosystem function. Biology International, Orsay, v. 33, s/n., p. 3-16, 1996 .

LEAL FILHO, N.; SANTOS, G. R.; FERREIRA, R. L. Comparando técnicas de nucleação utilizadas na restauração de áreas degradadas na Amazônia brasileira. Revista Árvore, Viçosa, v. 37, n. 4, p. 587-597, 2013.

LIMA, K. D. R. Avaliação de espécies arbóreas e técnicas de plantio para recuperação de áreas degradadas por extração de piçarra na Caatinga, RN. 2012. 86 f. Dissertação (Mestrado em Ciência do Solo: Área de Concentração em Manejo do Solo) - Universidade Federal Rural do Semi-Árido, Mossoró, 2012

LIMA, K. D. R. et al. Seleção de espécies arbóreas para revegetação de áreas degradadas por mineração de piçarra na Caatinga. Revista Caatinga, Mossoró, v. 28 , n. 1, p. 203-213, 2015

MACEDO, M. O. et al. Changes in soil $\mathrm{C}$ and $\mathrm{N}$ stocks and nutrient dynamics 13 years after recovery of degraded land using leguminous nitrogen-fixing trees. Forest Ecology and Management, New York, v. 255, n. 5-6, p. 1516-1524, 2008.

MARTINS, K. G. et al. Effects of soil conditions on the diversity of tropical forests across a successional 
gradient., Forest Ecology and Management, New York, v. 349, n. 1, p. 4-11, 2015.

NEGRETE-YANKELEVICH, S. et al. Spatial patchiness of litter, nutrients and macroinvertebrates during secondary succession in a Tropical Montane Cloud Forest in Mexico. Plant and Soil, Netherlands, v. 286, n. 1, p. 123-139, 2006.

NEHER, D. A. Role of nematodes in soil health and their use as indicators. Journal of Nematology, Hanover, v. 33, n. 4, p. 161-168, 2001.

NUNES, L. A. P. L.; ARAUJO FILHO, J. A.; MENEZES, R. I. Q. Diversidade da fauna edáfica em solos submetidos a diferentes sistemas de manejo no semi-árido nordestino. Scientia Agrária, Curitiba, v. 25, n. 1, p. 43-49, 2009.

NUNES, L. A. P. L. et al. Caracterização da fauna edáfica em sistemas de manejo para produção de forragens no Estado do Piauí. Revista Ciência Agronômica, Fortaleza, v. 43, n. 1, p. 30-37, 2012.

NUNES, L. A. P. L. et al. Recolonização da fauna edáfica em áreas de Caatinga submetidas a queimadas. Revista Caatinga, Mossoró, v. 21, n. 3, p. 214-220, 2008.

ODUM, E. P. Ecologia. 1. ed. Rio de Janeiro, RJ: Editora Guanabara Koogan, 1988. 434 p.

PEREIRA, G. H. A. et al. Decomposição da serrapilheira, diversidade e funcionalidade de invertebrados do solo em um fragmento de floresta atlântica. Bioscience Journal, Uberlândia, v. 29, n. 5 , p. $1317-1327,2013$.

RESENDE, A. S. D.; CHAER, G. M. Manual para recuperação de áreas degradadas por exploração de piçarra na Caatinga. 1. ed. Seropédica, RJ: Embrapa Agrobiologia, 2010. 78 p.

RESENDE, A. S. et al. Produção e qualidade de mudas de espécies florestais. In: RESENDE, A. S. D.; CHAER, G. M. (Eds.). Manual para recuperação de áreas degradadas por exploração de piçarra na Caatinga. Seropédica: Embrapa Agrobiologia, 2010. p. 13-28.

RESENDE A. S. et al. Uso de leguminosas arbóreas na recuperação de áreas degradadas. Tópicos em Ciência do Solo, Viçosa, v. 8, n. 1, p. 71-92, 2013.

SANTOS, H. G. et al. Sistema brasileiro de classificação de solos. 3. ed. Brasília, DF: EMBRAPA, 2013. 353 p.

SOUTO, P. C. et al. Comunidade microbiana e mesofauna edáficas em solo sob Caatinga no semi-árido da Paraíba. Revista Brasileira de Ciência do Solo, Viçosa, v. 32, n. 32, p. 151-160, 2008.

SZINWELSKI, N. et al. Effects of forest regeneration on crickets: evaluating environmental drivers in a 300-year chronosequence. International Journal of Zoology, New York, v. 2012, s/n., p. 1-13, 2012.

VELOSO, H. P.; RANGEL FILHO, A. L. R.; LIMA, J. C. A. Classificação da vegetação brasileira adaptada a um sistema universal. 1. ed. Rio de Janeiro, RJ: IBGE, 1991. 124 p.

WARDLE, D. A. Impacts of disturbance on detritus food-webs in agroecosystems of contrasting tillage and weed management practices. In: BEGON, M.; FITTER, A. H. (Eds.). Advances in ecological research. New York: Academic Press, 1995. v. 26. p. 105-185. 